\title{
Inhibitory Effects of Tea Leaf and Medicinal Plant Extracts on Enteric Pathogenic Bacteria Growth, Oxidation and Epithelial Cell Adhesion
}

\author{
Thida Kaewkod, Wilaiporn Songkhakul, Yingmanee Tragoolpua*
}

Thida Kaewkod, Wilaiporn Songkhakul, Yingmanee Tragoolpua*

\section{Department of Biology, Faculty of Science, Chiang Mai University, Chiang Mai, THAILAND.}

\section{Correspondence}

\section{Dr. Yingmanee Tragoolpua}

Department of Biology, Faculty of Science, Chiang Mai University, Chiang Mai-50200, THAILAND.

Email id: yboony150@gmail.com

\section{History}

- Submission Date: 29-10-2021:

- Review completed: 25-11-2021;

- Accepted Date: 09-12-2021.

DOI : 10.5530/pres.14.1.11

Article Available online http://www.phcogres.com

\section{Copyright}

(C) 2022 Phcog.Net. This is an openaccess article distributed under the terms of the Creative Commons Attribution 4.0 International license.

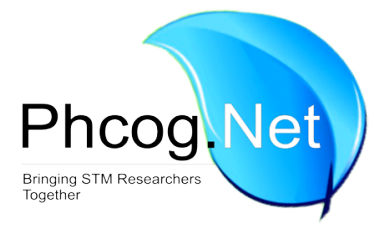

\begin{abstract}
Background: Diarrhea disease was noted by WHO as the major target for control that the leading cause of diarrhea diseases are enteric pathogenic bacteria. Biological properties of tea leaf and medicinal plant which promoted the alternative way to inhibit enteric pathogenic bacteria. Objectives: To investigate antibacterial activity of tea leaf combined with medicinal plant extracts for inhibition of growth and the adhesion of enteric pathogenic bacteria on epithelial cells. Materials and Methods: Among the Camellia sinensis tea leaves; green, oolong and black tea, and 14 medicinal plants examined, aqueous and ethanolic extracts demonstrated growth inhibition against Escherichia coli, Salmonella typhi, Shigella dysenteriae, Staphylococcus aureus and Vibrio cholerae. Antioxidation, phenolics and flavonoids contents were also determined. Tea leaf and medicinal plant extracts were combined for the development of herbal tea that subsequently evaluated the inhibition of bacterial adhesion on epithelial cells. Results: The aqueous and ethanolic extracts of green tea and Garcinia cowa showed effectiveness against all enteric pathogenic bacteria, especially the fraction of ethanolic extracts that revealed the greatest bactericidal activity. Moreover, the ethanolic extract of green tea showed the highest content of phenolics and flavonoids, which also correlated with the antioxidant activity. In addition, the ethanolic extract of G. cowa had the highest flavonoid content. Hence, the combination of green tea with $G$. cowa extract revealed its effectiveness against enteric pathogenic bacteria and had an inhibitory effect against the adhesion of bacteria on epithelial cells. Conclusion: Herbal tea, the combination of green tea and $G$. cowa extract exhibited the beneficial antibacterial and antioxidant activities, which could be considered as an alternative treatment for enteric pathogenic bacteria infections and promote health benefits.
\end{abstract}

Key words: Antioxidation, Cell adhesion, Enteric pathogenic bacteria, Herbal tea, Medicinal plant, Tea leaf.

\section{INTRODUCTION}

Infections of enteric pathogenic bacteria can cause public health concerns worldwide. The enteric bacteria are important causative agents of foodborne disease. These bacteria include members of the Enterobacteriaceae such as Escherichia, Shigella, Salmonella, Enterobacter, Proteus and Yersinia, and can cause gastrointestinal diseases with symptoms such as diarrhea, vomiting and abdominal pain. ${ }^{[1]}$ The mechanisms of enteric pathogenic bacterial infections involve several distinct pathogenic pathways. They can adhere and multiply at the epithelial cells before entering internal tissues. Almost all of their strains can produce toxins, which lead to severe diseases in humans. Enterotoxin produced from E. coli is associated to cause watery diarrhea and vomiting symptoms. ${ }^{[2]}$ In addition, V. cholerae produces a cholera toxin, which is a complex A-B toxin and similar to the heat-labile enterotoxin of E. coli. These toxins can cause the hypersecretion of water and electrolytes in severe diseases. ${ }^{[3]}$ The treatment of infection consists of mainly replacing fluids and salts within 4-8 days without antibiotics. In severe cases, the patients are treated with antibiotics such as trimethoprimsulfamethoxazole and ciprofloxacin in adults. Additionally, the risk of the infection might be distributed to other people. ${ }^{[4]}$ Although antibiotics are synthetic agents for treatment of diseases, they could induce many side effects to patients such as toxicity, and resistant strains of bacteria may emerge after using antibiotics for long time. ${ }^{[5]}$

To date, natural products from medicinal plants have been employed to treat microbial infections. Bioactive compounds founded in the plants such as flavonoid and phenolic compounds have many beneficial activities such as antimicrobial, antiinflammation, anticancer and antioxidantactivities. ${ }^{[6]}$
Cite this article: KaewkodT, SongkhakulW, TragoolpuaY. Inhibitory Effects of Tea Leaf and Medicinal Plant Extracts on Enteric Pathogenic Bacteria Growth, Oxidation and Epithelial Cell Adhesion. Pharmacog Res. 2022;14(1):71-81. 
Young leaves of Camellia sinensis can be used to produce tea that is popularly consumed beverage worldwide. Moreover, it can be used for the production of green tea, oolong tea and black tea. Types of tea are processed in different polyphenol oxidation, and various amounts of phytochemical compounds were found during the tea processing. ${ }^{[7]}$ Green tea leaves were produced directly from fresh leaves without fermentation and contained the richest original polyphenol content, including mainly flavanols or catechins such as epigallocatechin gallate (EGCG), epicatechin gallate (ECG) and epicatechins (EC). Oolong tea is can be called as the semi-fermented tea, whereas black tea is fully fermented in the process of tea production. The most polyphenols in black tea are found to be thearubigins and theaflavins. Oolong tea contains half the content of catechins when paralleled to green tea. ${ }^{[8,9]}$ Previous studies have discovered that polyphenols in tea have been used to inhibit enteric pathogenic bacteria such as Salmonella typhi, S. typhimurium and Staphylococcus aureus and also inhibited oral bacteria such as Streptococcus mutans, Porphyromonas gingivalis. ${ }^{[10]}$

In Thailand, the product of herbal tea, including herbal infusion beverages, is widely consumed by many people. Herb or medicinal plants have been used as the natural substances of antibiotics for traditional medicines, modern medicines, food supplements, nutraceuticals, pharmaceuticals and chemical entities for synthetic drugs. ${ }^{[1]}$ In addition, medicinal plants contain a high content of phenolic and flavonoids, which are associated with antioxidant activities and promote the prevention of diseases. ${ }^{[12]}$ The beneficial components in both tea and medicinal plants have been reported to comprise many health-promoting features such as protection from diabetes, obesity and cardiovascular diseases. Moreover, the medicinal plants and tea demonstrated anticarcinogen, anti-aging, anti-histamine, anti-arthritis, anti-inflammation, anti-bacteria, anti-fungus, and anti-viral effect. ${ }^{[12,13]}$ This research will promote the efficacy of herbal tea by combination of tea with medicinal plants. However, the studies on other herbal teas or their components are limited, there is expansive literature reporting the health benefits of herbal tea. For example, chamomile tea contains the benefits of antioxidant, hypocholesterolemic, anticancer and anti-inflammatory effects. ${ }^{[14]}$ The composition of herbal tea usually consists of at least one or more type of herb that is dependent on tastes, smells and compatibility between tea and each herb. The purpose of this study was to evaluate phytochemical compounds, anti-free radical and antibacterial activities from green tea, oolong tea, black teas and 14 Thai herbs. In addition, we have evaluated the synergistic effect of tea leaf and medicinal plant extracts for inhibition of the growth and adhesion of enteric pathogenic bacteria on epithelial cells.

\section{MATERIALS AND METHODS}

\section{Plant materials}

The dried tea leaves such as green tea, oolong tea and black tea were kindly provided from Tea Gallery Group (Thailand) Co., Ltd, Chiang Mai, Thailand. Fourteen medicinal plants used in this study were Archidendron clypearia (peel), Cananga odorata (flower), Chrysanthemum indicum (flower), Cleistocalyx nervosum (fruit), Clitoria ternatea (flower), Garcinia cowa (leaf), Garcinia mangostana (peel), Hibiscus sabdariffa (flower), Jasminum officinale (flower), Mesua ferrea (flower), Mentha cordifolia (leaf), Mimusops elengi (flower), Nelumbo nucifera (flower) and Zingiber officinale (rhizome). The plant materials were purchased from local markets in Chiang Mai, Thailand. The plants were washed, cut in to small sizes and spread on a tray for air drying under a hot air oven at $55^{\circ} \mathrm{C}$ for 3 days before powdered using a grinder.

\section{Plant extracts preparation}

The plant samples were extracted in distilled water and 95\% ethanol, with a 1:10 ratio of material to solvent. ${ }^{[15]}$ The plant samples were soaked in distilled water and incubated at $45^{\circ} \mathrm{C}$ in a water bath for $3 \mathrm{hr}$. For the ethanolic extracts, the plants were soaked at room temperature for 3 days. ${ }^{[16]}$ The extraction was performed twice and the extracts were filtered by Whatman no.1 filter paper. After, the solvent extraction was removed using a rotary evaporator. The extracts were then dried by lyophilization. The crude extract was stored at $-20^{\circ} \mathrm{C}$ for further study. The extracts were adjusted to obtain a final concentration of $500 \mathrm{mg} / \mathrm{mL}$ using sterile distilled water and dimethyl sulfoxide, DMSO for dissolving of the aqueous extracts and ethanolic extracts, respectively.

\section{Bacterial culture}

The enteric pathogenic bacteria was used for the investigation of antimicrobial activity including Escherichia coli, Vibrio cholerae, Salmonella typhi DMST 22842, Shigella dysenteriae DMST 1511 and Staphylococcus aureus ATCC 25923. The bacterial strains were kept in glycerol stock at $-20^{\circ} \mathrm{C}$ and then grown on Mueller-Hinton (MH) agar plates (Difco ${ }^{\mathrm{mn}}$, Detroit, MI, USA) at $37^{\circ} \mathrm{C}$ for $18-24 \mathrm{hr}$.

\section{Antibacterial activity by agar disc diffusion method}

The inhibition of enteric pathogenic bacteria was determined by the agar disc diffusion method. ${ }^{[17]}$ Bacterial strains were inoculated into $\mathrm{MH}$ broth and incubated at $37^{\circ} \mathrm{C}$ for $18-24 \mathrm{hr}$. The bacteria were adjusted to McFarland standard No. $0.5\left(10^{8} \mathrm{CFU} / \mathrm{mL}\right)$ and swabbed on to Mueller Hinton agar (MHA). The paper discs were soaked in tea leaves and plant extracts, and placed on the agar plates. After incubation, the diameter of the inhibition zone was measured. A standard of $10 \mu \mathrm{g} / \mathrm{mL}$ gentamycin disc was used as a positive control. The synergistic activity of the crude extracts of green tea, oolong tea and black tea combined with some of the selected medicinal plant extracts were evaluated at a ratio of 1:1.

\section{Minimal inhibitory concentration (MIC) and minimal bactericidal concentration (MBC)}

MIC was determined by the micro-dilution method using serially diluted (2-fold) plant extracts according to the CLSI. ${ }^{[18]}$ The MIC and MBC of ethanolic and aqueous extracts of the plant extracts were determined. The bacterial inoculum was adjusted to McFarland standard No. 0.5. The test tubes were incubated at $37^{\circ} \mathrm{C}$ for $24 \mathrm{hr}$. The MIC was determined to have the lowest concentration of the extract showing no growth of bacteria, and were streaked on a plate on MHA to determine the MBC. Bacterial growth was determined after 18-24 hr of incubation. The MBC had the lowest concentration that inhibited the growth of bacteria by $99.9 \%$.

\section{Time killing assay of bacteria}

Time killing assay of bacteria by treatment with plant extracts was demonstrated using a modified plating technique. ${ }^{[19]}$ After the treatment of the bacteria $\left(1.8 \times 10^{5} \mathrm{CFU} / \mathrm{mL}\right)$ with the extract at $37^{\circ} \mathrm{C}$, the sample $(100 \mu \mathrm{L})$ was taken at $0,3,6,9,12$ and $24 \mathrm{hr}$ and serially diluted in sterile distilled water before being spread on a plate on $\mathrm{MH}$ agar. The plates were incubated at $37^{\circ} \mathrm{C}$ for $24 \mathrm{hr}$ and the formed colonies were counted on the medium. The total count of bacteria was expressed as colony forming units $(\mathrm{CFU} / \mathrm{mL})$ and calculated the percentage of inhibition by comparing to the bacterial control.

\section{Free radical scavenging activity}

The plant extracts was investigated by DPPH method. ${ }^{[20]}$ Briefly, the mixture between $0.5 \mathrm{~mL}$ of the sample $(0.001-10 \mathrm{mg} / \mathrm{mL})$ and $1.5 \mathrm{~mL}$ of DPPH solution $(0.1 \mathrm{mM}$ in methanol) was added into each test tube. The reaction was incubated in the dark at room temperature at $20 \mathrm{~min}$. The 
absorbance was detected by spectrophotometer at $517 \mathrm{~nm}$. Methanol was used as a blank control, while DPPH without plant extract was used as a radical control. The DPPH radical scavenging activity was calculated in the percent value as follows:

Percentages of DPPH free radical scavenging activity $(\%)=$

$$
\left[\left(A_{0}-A_{1}\right) / A_{0}\right] \times 100
$$

Where $A_{0}$ was the absorbance of the DPPH solution and $A_{1}$ was the absorbance of the sample mixed with the DPPH solution. The concentrations providing $50 \%$ scavenging $\left(\mathrm{IC}_{50}\right.$ ) were calculated from the graph plotted between the free radical scavenging percentages and the sample concentrations. The antioxidant capacity of the plant extract was expressed by comparing the samples to standard compound (gallic acid) and was revealed as milligrams of gallic acid per gram of extract (mg GAE/g extract).

\section{Total phenolic compound}

The extracts was determined the content of total phenolic compounds by the colorimetric Folin-Ciocalteu method as described by Ghasemi. ${ }^{[21]}$ Briefly, the extracts were diluted in methanol and added into each test tube. Next, 50\% Folin-Ciocalteu reagent $(125 \mu \mathrm{L})$ and $95 \%$ ethanol $(250 \mu \mathrm{L})$ were added into each well. The reaction was incubated in the dark at room temperature for $5 \mathrm{~min}$. In addition, sodium carbonate $(250 \mu \mathrm{L})$ was then added and further incubated in the dark at room temperature for $60 \mathrm{~min}$. The developed blue color was measured to determine the absorbance at $725 \mathrm{~nm}$ using a spectrophotometer. The total phenolic content was calculated by comparing the samples to standard compound (gallic acid) and was revealed as milligrams of gallic acid per gram of extract (mg GAE/g extract).

\section{Total flavonoid compound}

The total flavonoid content of different crude extracts were estimated with the aluminum chloride colorimetric method as described by Ghasemi. ${ }^{[21]}$ The crude extracts $(0.5 \mathrm{~mL})$ were prepared and added into test tubes. The reaction was contained the mixture of deionized water $(2.8 \mathrm{~mL})$, methanol $(1.5 \mathrm{~mL}), 10 \%$ aluminum chloride $(0.1 \mathrm{~mL})$ and $1 \mathrm{M}$ potassium acetate $(0.1 \mathrm{~mL})$. After incubation in the dark at room temperature for $30 \mathrm{~min}$, the absorbance values were measured at $415 \mathrm{~nm}$ using a spectrophotometer. The total flavonoid content was calculated by comparing the samples to standard compound (quercetin) and was revealed as milligrams of quercetin per gram of extract (mg QUE/g extract).

\section{Cytotoxicity assay}

The cytotoxicity was performed using Vero cells, and 50\% cytotoxicity dose $\left(\mathrm{CD}_{50}\right)$ was determined. ${ }^{[22]}$ The Vero cell was grown in Minimum essential medium (MEM) supplementary with $10 \%$ heat-inactivated fetal bovine serum (FBS). The cells were incubated in $5 \% \mathrm{CO}_{2}$ incubator at $37^{\circ} \mathrm{C}$. The cells $\left(10^{5}\right.$ cells $\left./ \mathrm{mL}\right)$ were seeded into a 96 -well tissue-culture plate in complete MEM and incubated for $24 \mathrm{hr}$. The extract was 2 -fold diluted with MEM medium and the extract was added into each well. After treatment for $72 \mathrm{hr}$, the cells were stained with crystal violet $(0.1 \%)$ for $15 \mathrm{~min}$ and $\mathrm{CD}_{50}$ values were calculated.

\section{Anti-bacterial adhesion assay}

The Vero cell was grown in MEM supplementary with $10 \%$ heatinactivated FBS and incubated in $5 \% \mathrm{CO}_{2}$ incubator at $37^{\circ} \mathrm{C}$. The cells at the concentration of $10^{2}$ cells $/ \mathrm{mL}$ were transferred into 6-well tissueculture plates, which contained the sterile cover slips. The plates were incubated for $24 \mathrm{hr}$ for cell stabilization. ${ }^{[23,24]}$ The cells were incubated with the bacterial culture $\left(10^{5} \mathrm{CFU} / \mathrm{mL}\right)$ and the crude extract at nontoxic concentrations on the epithelial cell. The adhesion activity of bacteria on cells was incubated at $37^{\circ} \mathrm{C}$ for $2 \mathrm{hr}$. The normal cells and infected cells were infected with bacteria in absence of plant extract were included as a negative and positive control. After washing with phosphate-buffered saline 3 times, the cells were fixed with methanol, stained with Giemsa $0.38 \%$ v/v, and examined microscopically under oil immersion at $100 \mathrm{X}$. The adherent bacteria on 100 epithelial cells were counted using a compound microscope. The percentage of the inhibition of bacterial adhesion was expressed and compared to the cell control.

\section{Statistical analysis}

All data were performed by way of three independent experiments on separate occasions. The results were presented as mean \pm SD values of the independent sample. T-test and ANOVA analysis were used to analyze results of both the treatment and control groups.

\section{RESULTS}

\section{Plant extracts}

Plants including tea leaves (green tea, oolong tea and black tea), and 14 medicinal plants; Archidendron clypearia, Cananga odorata, Chrysanthemum indicum, Cleistocalyx nervosum, Clitoria ternatea, Garcinia cowa, Garcinia mangostana, Hibiscus sabdariffa, Jasminum officinale, Mesua ferrea, Mentha cordifolia, Mimusops elengi, Nelumbo nucifera and Zingiber officinale were extracted using distilled water and ethanol solvents. After evaporation and lyophilization, the extraction yield of most aqueous extracts was higher than the ethanolic extracts (Table 1). For tea leaves, the highest percentage yield of $28.57 \%$ was from green tea, which was extracted by water, followed by an aqueous extract of oolong tea and ethanolic extract of green tea. Moreover, the medicinal plant extracted by water extraction of $N$. nuclfera showed the highest percentage yield with the value of 68.77 , followed by C. nervosum and

Table 1: Percentage of extraction yields of plant extracts.

\begin{tabular}{|c|c|c|c|}
\hline \multirow[b]{2}{*}{ Plants } & \multirow[b]{2}{*}{ Part used } & \multicolumn{2}{|c|}{ Extraction yields (\%) } \\
\hline & & $\begin{array}{c}\text { Aqueous } \\
\text { extract }\end{array}$ & $\begin{array}{c}\text { Ethanolic } \\
\text { extract }\end{array}$ \\
\hline \multicolumn{4}{|c|}{ Tea leaves } \\
\hline green tea & leaf & 28.57 & 15.13 \\
\hline oolong tea & leaf & 28.34 & 10.11 \\
\hline black tea & leaf & 13.91 & 2.22 \\
\hline \multicolumn{4}{|c|}{ Medicinal plants } \\
\hline Archidendron clypearia & peel & 16.26 & 49.08 \\
\hline Canaga odorata & flower & 52.43 & 26.59 \\
\hline Chrysanthemum indicum & flower & 32.29 & 22.85 \\
\hline Cleistocalyx nervosum & fruit & 64.28 & 39.23 \\
\hline Clitoria ternatea & flower & 39.25 & 26.13 \\
\hline Garcinia cowa & Leaf & 40.54 & 35.22 \\
\hline Garcinia mangostana & peel & 33.47 & 16.94 \\
\hline Hibiscus sabdariffa & flower & 38.55 & 18.44 \\
\hline Jasminum officinale & flower & 34.04 & 15.97 \\
\hline Mesua ferrea & flower & 24.25 & 21.29 \\
\hline Metha cordifolia & leaf & 28.77 & 11.32 \\
\hline Mimusops elengi & flower & 18.59 & 9.25 \\
\hline Nelumbo nuclfera & flower & 68.77 & 15.04 \\
\hline Zingiber officinale & rhizome & 10.09 & 9.89 \\
\hline
\end{tabular}


C. odorata. Additionally, each plant extract showed different colors from dark brown to yellow.

\section{Antibacterial activity of plant extracts}

Green, oolong, and black tea leaves at a concentration of $500 \mathrm{mg} / \mathrm{mL}$ were tested for antimicrobial activities on enteric pathogenic bacteria including Escherichia coli, Salmonella typhi, Shigella dysenteriae, Staphylococcus aureus and Vibrio cholera. The results presented that the aqueous extracts of green and oolong tea leaves revealed antibacterial activity against all tested bacteria. The diameter of clear zone of the bacteria after treatment by the aqueous extracts of green tea and oolong tea ranged from $7.33 \pm 0.58-14.0 \pm 5.66 \mathrm{~mm}$ (Table 2). In addition, the aqueous extracts of all tea leaves had the lowest MIC and MBC value of $250 \mathrm{mg} / \mathrm{mL}$ for inhibition of all tested bacteria (Table 3). Moreover, the ethanolic extracts of green and oolong and black tea leaves had the ability to inhibit all tested enteric pathogenic bacteria that represented the diameter of clear zone ranging from $8.00 \pm 1.00-24.33 \pm 0.58 \mathrm{~mm}$ respectively (Table 4). Additionally, the ethanolic extract of green, oolong and black tea presented the MIC and MBC values ranging from $62.50-250 \mathrm{mg} / \mathrm{mL}$ (Table 5).

Moreover, this study demonstrated that the aqueous extracts of Archidendron clypearia, Cleistocalyx nervosum, Garcinia cowa and Mimusops elengi could inhibit the growth of all tested enteric pathogenic bacteria (Table 2). In addition, the ethanolic extracts of A. clypearia, C. nervosum (fruit), G. cowa, M. elengi and Nelumbo nuclfera had the ability to inhibit all tested enteric pathogenic bacteria (Table 3). Specifically, the aqueous and ethanolic extracts of G. cowa had the greatest inhibitory effect against all enteric pathogenic bacteria, which was represented in the diameter of clear zone ranging from $12.67 \pm 0.58$ to $22.33 \pm 1.53 \mathrm{~mm}$ (Table 2 and 3 ). Moreover, the aqueous and ethanolic extracts of $G$. cowa revealed the MIC and MBC values ranging from 15.63 to $31.25 \mathrm{mg} / \mathrm{mL}$ (Table 4 and 5).

\section{Time-kill kinetics of enteric pathogenic bacteria by medicinal plant extracts}

The antibacterial activities of medicinal plant extracts were analyzed by time-kill kinetics. Both aqueous and ethanolic extracts of $G$. cowa were selected, which showed the greatest inhibitory effect against all enteric pathogenic bacteria. The time-kill kinetics profile was determined using these extracts at MIC concentrations against E. coli, S. typhi, $S$. dysenteriae and V. cholera. The results were demonstrated in terms of the changes in the $\log _{10} \mathrm{cfu} / \mathrm{mL}$ of viable colonies, which displayed that the extract represented significant bactericidal activity. After incubating the aqueous extract of G. cowa with S. typhi and V. cholerae, the average $\log$ reduction in the viable cell decreased within $3 \mathrm{~h}$. Moreover, the aqueous extract of $G$. cowa could inhibit E. coli and $S$. dysenteriae within $9 \mathrm{~h}$ (Figure 1). For the time-kill kinetic of the G. cowa ethanolic extract, the average log reduction in the viable cell was decreased within $3 \mathrm{hr}$ after these extracts were incubated with S. typhi. In addition, the ethanolic extract of G. cowa could inhibit E. coli, S. dysenteriae and $V$. cholerae within $9 \mathrm{hr}$ (Figure 2).

Table 2: Antibacterial activity of the aqueous extracts against enteric pathogenic bacteria by agar diffusion method.

\begin{tabular}{|c|c|c|c|c|c|}
\hline \multirow{2}{*}{ Plant extracts } & \multicolumn{5}{|c|}{ Inhibition zone diameter $(\mathrm{mm})$ of tested bacteria } \\
\hline & E. coli & S. typhi & S. dysenteriae & S. aureus & V. cholerae \\
\hline \multicolumn{6}{|l|}{ Tea leaves } \\
\hline Green tea & $13.37 \pm 1.58$ & $10.50 \pm 0.35$ & $10.10 \pm 0.35$ & $14.00 \pm 5.66$ & $10.6 \pm 0.15$ \\
\hline Oolong tea & $11.30 \pm 1.00$ & $7.33 \pm 6.35$ & $9.22 \pm 1.30$ & $13.70 \pm 5.49$ & $7.33 \pm 0.58$ \\
\hline Black tea & $6.93 \pm 6.00$ & $10.10 \pm 1.00$ & $7.23 \pm 6.26$ & 0 & $6.07 \pm 5.07$ \\
\hline \multicolumn{6}{|l|}{ Medicinal plants } \\
\hline Archidendron clypearia & $9.67 \pm 0.58$ & $7.00 \pm 0.00$ & $8.67 \pm 1.15$ & $16.00 \pm 1.00$ & $7.33 \pm 0.58$ \\
\hline Canaga odorata & 0 & 0 & 0 & 0 & 0 \\
\hline Chrysanthemum indicum & 0 & 0 & 0 & 0 & 0 \\
\hline Cleistocalyx nervosum & $9.33 \pm 1.15$ & $11.67 \pm 2.08$ & $10.33 \pm 0.58$ & $11.33 \pm 0.58$ & $11.00 \pm 1.73$ \\
\hline Clitoria ternatea & 0 & 0 & 0 & 0 & 0 \\
\hline Garcinia cowa & $13.33 \pm 2.31$ & $12.67 \pm 2.08$ & $12.67 \pm 0.58$ & $20.33 \pm 1.53$ & $13.00 \pm 1.73$ \\
\hline Garcinia mangostana & 0 & $7.33 \pm 0.58$ & 0 & $11.00 \pm 0.00$ & 0 \\
\hline Hibiscus sabdariffa & 0 & 0 & 0 & 0 & 0 \\
\hline Jasminum officinale & 0 & 0 & 0 & 0 & 0 \\
\hline Mesua ferrea & $9.67 \pm 0.58$ & 0 & 0 & $12.00 \pm 0.00$ & 0 \\
\hline Metha cordifolia & 0 & 0 & 0 & $9.33 \pm 0.58$ & 0 \\
\hline Mimusops elengi & $9.67 \pm 0.58$ & $9.67 \pm 0.58$ & $9.67 \pm 0.58$ & $12.00 \pm 0.00$ & $9.00 \pm 1.00$ \\
\hline Nelumbo nuclfera & 0 & 0 & 0 & 0 & 0 \\
\hline Zingiber officinale & 0 & $15.33 \pm 0.58$ & 0 & $12.00 \pm 1.00$ & 0 \\
\hline Gentamycin $(10 \mu \mathrm{g} / \mathrm{mL})$ & $20.00 \pm 0.00$ & $20.00 \pm 0.00$ & $20.00 \pm 0.00$ & $23.00 \pm 0.00$ & $23.00 \pm 0.00$ \\
\hline
\end{tabular}

These results are presented as mean \pm SD of triplicate independent experiments. 
Table 3: MIC and MBC values of aqueous extracts against enteric pathogenic bacteria.

\begin{tabular}{|c|c|c|c|c|c|}
\hline \multirow{3}{*}{ Plant extracts } & \multicolumn{5}{|c|}{ MIC and MBC of plant extracts $(\mathrm{mg} / \mathrm{mL})$} \\
\hline & E. coli & S. typhi & S. dysenteriae & S. aureus & V. cholerae \\
\hline & $\mathrm{MIC} / \mathrm{MBC}$ & $\mathrm{MIC} / \mathrm{MBC}$ & $\mathrm{MIC} / \mathrm{MBC}$ & MIC / MBC & $\mathrm{MIC} / \mathrm{MBC}$ \\
\hline \multicolumn{6}{|l|}{ Tea leaves } \\
\hline Green tea & $250 / 250$ & $250 / 250$ & $250 / 250$ & $250 / 250$ & $250 / 250$ \\
\hline Oolong tea & $250 / 250$ & $250 / 250$ & $250 / 250$ & $250 / 250$ & $250 / 250$ \\
\hline Black tea & $250 / 250$ & $250 / 250$ & $250 / 250$ & $250 / 250$ & $250 / 250$ \\
\hline \multicolumn{6}{|l|}{ Medicinal plants } \\
\hline Archidendron clypearia & $250 / 250$ & $250 / 250$ & $250 / 250$ & $250 / 250$ & $250 / 250$ \\
\hline Cleistocalyx nervosum & $62.50 / 62.50$ & $62.50 / 62.50$ & $62.50 / 62.50$ & $62.50 / 62.50$ & $15.25 / 15.25$ \\
\hline Garcinia cowa & $15.63 / 15.63$ & $15.63 / 15.63$ & $31.25 / 31.25$ & $15.63 / 15.63$ & $31.25 / 31.25$ \\
\hline Garcinia mangostana & $>500 />500$ & $250 / 250$ & $>500 />500$ & $62.50 / 62.50$ & $>500 />500$ \\
\hline Mesua ferrea & $250 / 250$ & $>500 />500$ & $>500 />500$ & $250 / 250$ & $>500 />500$ \\
\hline Metha cordifolia & $>500 />500$ & $>500 />500$ & $>500 />500$ & $250 / 500$ & $>500 />500$ \\
\hline Mimusops elengi & $250 / 250$ & $250 / 250$ & $250 / 250$ & $62.50 / 62.50$ & $250 / 250$ \\
\hline Zingiber officinale & $>500 />500$ & $>500 />500$ & $>500 />500$ & $125 / 125$ & $62.50 / 62.50$ \\
\hline Gentamycin $(\mu \mathrm{g} / \mathrm{mL})$ & $5.0 / 2.5$ & $2.5 / 2.5$ & $2.5 / 2.5$ & $2.5 / 2.5$ & $5.0 / 2.5$ \\
\hline
\end{tabular}

These results are presented as mean \pm SD of triplicate independent experiments.

Table 4: Antibacterial activity of the ethanolic extracts against enteric pathogenic bacteria by agar diffusion method.

\begin{tabular}{|c|c|c|c|c|c|}
\hline \multirow{2}{*}{ Plant extracts } & \multicolumn{5}{|c|}{ Inhibition zone diameter $(\mathrm{mm})$ of tested bacteria } \\
\hline & E. coli & S. typhi & S. dysenteriae & S. aureus & V. cholerae \\
\hline \multicolumn{6}{|l|}{ Tea leaves } \\
\hline Green tea & $13.67 \pm 0.58$ & $10.00 \pm 1.00$ & $11.33 \pm 0.58$ & $24.33 \pm 0.58$ & $10.67 \pm 0.58$ \\
\hline Oolong tea & $12.00 \pm 0.00$ & $11.33 \pm 1.53$ & $10.33 \pm 0.58$ & $24.00 \pm 1.00$ & $11.33 \pm 0.58$ \\
\hline Black tea & $12.33 \pm 1.53$ & $9.67 \pm 0.58$ & $11.33 \pm 0.58$ & $12.33 \pm 1.53$ & $8.00 \pm 1.00$ \\
\hline \multicolumn{6}{|l|}{ Medicinal plants } \\
\hline Archidendron clypearia & $9.67 \pm 0.58$ & $8.33 \pm 0.58$ & $10.67 \pm 0.58$ & $14.00 \pm 1.73$ & $8.67 \pm 0.58$ \\
\hline Canaga odorata & 0 & 0 & 0 & 0 & 0 \\
\hline Chrysanthemum indicum & 0 & 0 & 0 & 0 & 0 \\
\hline Cleistocalyx nervosum & $9.33 \pm 1.15$ & $11.67 \pm 2.08$ & $10.33 \pm 0.58$ & $11.33 \pm 0.58$ & $11.00 \pm 1.73$ \\
\hline Clitoria ternatea & 0 & 0 & 0 & 0 & 0 \\
\hline Garcinia cowa & $13.33 \pm 2.31$ & $12.67 \pm 2.08$ & $12.67 \pm 0.58$ & $22.33 \pm 1.53$ & $13.00 \pm 1.73$ \\
\hline Garcinia mangostana & 0 & 0 & 0 & $10.33 \pm 0.58$ & 0 \\
\hline Hibiscus sabdariffa & 0 & 0 & 0 & 0 & 0 \\
\hline Jasminum officinale & 0 & $7.00 \pm 0.00$ & 0 & 0 & 0 \\
\hline Mesua ferrea & 0 & 0 & $8.00 \pm 0.00$ & $8.00 \pm 0.00$ & 0 \\
\hline Metha cordifolia & 0 & $7.00 \pm 0.00$ & $7.3 \pm 0.58$ & $7.66 \pm 0.58$ & $7.00 \pm 0.00$ \\
\hline Mimusops elengi & $9.33 \pm 0.58$ & $9.00 \pm 0.00$ & $10.00 \pm 0.00$ & $10.33 \pm 0.58$ & $9.67 \pm 0.58$ \\
\hline Nelumbo nuclfera & $8.33 \pm 1.50$ & $8.67 \pm 0.60$ & $9.67 \pm 0.60$ & $10.00 \pm 0.00$ & $8.33 \pm 1.50$ \\
\hline Zingiber officinale & 0 & 0 & 0 & $12.00 \pm 1.00$ & 0 \\
\hline Gentamycin $(10 \mu \mathrm{g} / \mathrm{mL})$ & $20.00 \pm 0.00$ & $20.00 \pm 0.00$ & $20.00 \pm 0.00$ & $23.00 \pm 0.00$ & $23.00 \pm 0.00$ \\
\hline
\end{tabular}

These results are presented as mean \pm SD of triplicate independent experiments. 
Table 5: MIC and MBC values of ethanolic extracts against enteric pathogenic bacteria.

\begin{tabular}{|c|c|c|c|c|c|}
\hline \multirow{3}{*}{ Plant extracts } & \multicolumn{5}{|c|}{ MIC and MBC of plant extracts $(\mathrm{mg} / \mathrm{mL})$} \\
\hline & E. coli & S. typhi & S. dysenteriae & S. aureus & V. cholerae \\
\hline & MIC / MBC & $\mathrm{MIC} / \mathrm{MBC}$ & $\mathrm{MIC} / \mathrm{MBC}$ & $\mathrm{MIC} / \mathrm{MBC}$ & $\mathrm{MIC} / \mathrm{MBC}$ \\
\hline \multicolumn{6}{|l|}{ Tea leaves } \\
\hline Green tea & $250 / 250$ & $250 / 250$ & $250 / 250$ & $250 / 250$ & $250 / 250$ \\
\hline Oolong tea & $62.50 / 62.50$ & $125 / 125$ & $250 / 250$ & $250 / 250$ & $62.50 / 62.50$ \\
\hline Black tea & $62.50 / 62.50$ & $62.50 / 62.50$ & $250 / 250$ & $125 / 125$ & $62.50 / 62.50$ \\
\hline \multicolumn{6}{|l|}{ Medicinal plants } \\
\hline Archidendron clypearia & $125 / 125$ & $125 / 125$ & $62.50 / 62.50$ & $31.25 / 31.25$ & $125 / 125$ \\
\hline Cleistocalyx nervosum & $250 / 250$ & $125 / 125$ & $250 / 250$ & $62.50 / 62.50$ & $125 / 125$ \\
\hline Garcinia cowa & $15.63 / 15.63$ & $15.63 / 15.63$ & $15.63 / 15.63$ & $15.63 / 15.63$ & $15.63 / 15.63$ \\
\hline Garcinia mangostana & $>500 />500$ & $>500 />500$ & $>500 />500$ & $125 / 125$ & $>500 />500$ \\
\hline Jasminum officinale & $>500 />500$ & $125 / 125$ & $>500 />500$ & $>500 />500$ & $>500 />500$ \\
\hline Mesua ferrea & $>500 />500$ & $>500 />500$ & $125 / 125$ & $62.50 / 62.50$ & $>500 />500$ \\
\hline Metha cordifolia & $>500 />500$ & $31.25 / 31.25$ & $62.50 / 62.50$ & $15.63 / 15.63$ & $62.50 / 62.50$ \\
\hline Mimusops elengi & $125 / 125$ & $250 / 250$ & $125 / 125$ & $62.50 / 62.50$ & $250 / 250$ \\
\hline Nelumbo nuclfera & $125 / 125$ & $125 / 125$ & $250 / 250$ & $125 / 125$ & $125 / 125$ \\
\hline Zingiber officinale & $>500 />500$ & $>500 />500$ & $>500 />500$ & $250 / 250$ & $>500 />500$ \\
\hline Gentamycin $(\mu \mathrm{g} / \mathrm{mL})$ & $5.0 / 2.5$ & $2.5 / 2.5$ & $2.5 / 2.5$ & $2.5 / 2.5$ & $5.0 / 2.5$ \\
\hline
\end{tabular}

All values are presented as mean \pm SD of triplicate independent experiments.

\section{The radical scavenging activity of plant extracts}

The radical scavenging activity of plant extracts was determined against DPPH free radical by DPPH radical scavenging assay. The results presented that the aqueous and ethanolic extracts of green tea significantly showed the greatest antioxidant activity to inhibit DPPH radical, followed by oolong tea and black tea. The DPPH scavenging activity of the aqueous and ethanolic extract of green tea was $80.38 \pm 1.40$ and $116.15 \pm 9.47 \mathrm{mg} \mathrm{GAE} / \mathrm{g}$ extract (Table 6). For medicinal plant extracts, the aqueous and ethanolic extracts of A. clypearia significantly showed the greatest antioxidant activity to inhibit DPPH radical with the values of $138.48 \pm 3.62$ and $233.33 \pm 24.02 \mathrm{mg} \mathrm{GAE} / \mathrm{g}$ extract (Table 6).

\section{Total phenolic compound content of plant extracts}

The total phenolic content in plant extracts was determined by Folinciocalteu's reagent. The highest phenolic content of tea leaves was found from the aqueous and ethanolic extract of green tea, with the value of $12.86 \pm 0.11$ and $101.57 \pm 3.50 \mathrm{mg} \mathrm{GAE} / \mathrm{g}$ extract. Oolong tea and black tea showed total phenolic content that was less than green tea (Table 6). For medicinal plant extracts, A. clypearia aqueous extract and G. mangostana ethanolic extract had the highest total phenolic content, with the values of $109.14 \pm 2.50$ and $155.73 \pm 0.29 \mathrm{mg} \mathrm{GAE} / \mathrm{g}$ extract (Table 6).

\section{Total flavonoid content of plant extracts}

The total flavonoid content in plant extracts was determined by aluminum chloride colorimetric method. The highest flavonoid content of tea leaves was found in the aqueous and ethanolic extracts of green tea with the values of $105.42 \pm 1.98$ and $409.42 \pm 3.50 \mathrm{mg}$ QUE/g extract, followed by oolong and black tea (Table 6). For medicinal plant extracts, high content of flavonoid was found from A. clypearia aqueous extract and G. cowa ethanol extract, which had values of $238.54 \pm 19.12$ and $365.54 \pm 10.00 \mathrm{mg}$ QUE/g extract (Table 6).

\section{Antibacterial activity of the combination of tea leaf extract with plant extract}

The tea leaf and medicinal plant extracts with the highest antibacterial activity were selected and used to prepare the combination of tea leaves and plant extracts. This study demonstrated that green tea extracts had the greatest inhibitory effect on all enteric pathogenic bacteria, and also included the highest biological activities of antioxidation, phenolics and flavonoids. In addition, the extracts of G. cowa had the highest inhibitory activity against all enteric pathogenic bacteria, contained phenolic and flavonoid compounds, and demonstrated antioxidant activity. The maximum concentration of tea leaf extracts $(500 \mathrm{mg} / \mathrm{mL})$ was combined with a high dose of $G$. cowa extracts $(500 \mathrm{mg} / \mathrm{mL}$ ) and was studied for antibacterial activities.

The antibacterial activity of green tea extracts combined with G. cowa extracts was studied by agar disc diffusion method. The mixture was tested for antibacterial activities on enteric pathogenic bacteria including E. coli, S. typhi, S. dysenteriae, V. cholera and S. aureus. The results showed that the ethanolic extract of green tea combined with G. cowa exhibited antibacterial activity against all tested bacteria (Table 7). The clear zone inhibition of the ethanolic extract of green tea combined with G. cowa ranged from $14.00 \pm 1.00-20.67 \pm 0.58 \mathrm{~mm}$. In addition, the ethanolic extract of green tea combined with G. cowa showed the lowest MIC and MBC against $S$. aureus with the values of $0.97 \mathrm{mg} / \mathrm{mL}$ and presented the MIC and MBC values ranging from $0.97-15.63 \mathrm{mg} / \mathrm{mL}$ against all enteric pathogenic bacteria (Table 7). 
Table 6: Antioxidant activity, total phenolic compound and total flavonoid content of plant extracts.

\begin{tabular}{|c|c|c|c|c|c|c|}
\hline \multirow[t]{2}{*}{ Plant extracts } & \multicolumn{2}{|c|}{$\begin{array}{l}\text { Antioxidant activity } \\
\text { (mg GAE/g extract) }\end{array}$} & \multicolumn{2}{|c|}{$\begin{array}{c}\text { Total phenolic compound } \\
\text { (mg GAE/g extract) }\end{array}$} & \multicolumn{2}{|c|}{$\begin{array}{c}\text { Total flavonoid content } \\
\text { (mg QUE/g extract) }\end{array}$} \\
\hline & Aqueous extract & Ethanolic extract & Aqueous extract & Ethanolic extract & Aqueous extract & Ethanolic extract \\
\hline \multicolumn{7}{|l|}{ Tea leaves } \\
\hline Green tea & $80.38 \pm 1.40^{*}$ & $116.15 \pm 9.47^{*}$ & $12.86 \pm 0.11^{*}$ & $101.57 \pm 3.50^{*}$ & $105.42 \pm 1.98^{*}$ & $409.42 \pm 3.50^{*}$ \\
\hline Oolong tea & $27.46 \pm 2.47$ & $81.42 \pm 8.14$ & $9.53 \pm 0.16$ & $96.37 \pm 2.60$ & $69.61 \pm 3.23$ & $394.44 \pm 26.09$ \\
\hline Black tea & $21.45 \pm 0.72$ & $22.6 \pm 1.66$ & $7.23 \pm 0.05$ & $34.14 \pm 1.08$ & $53.66 \pm 1.63$ & $240.75 \pm 14.83$ \\
\hline \multicolumn{7}{|l|}{ Medicinal plants } \\
\hline Archidendron clypearia & $138.48 \pm 3.62^{*}$ & $233.33 \pm 24.02^{*}$ & $109.14 \pm 2.50^{*}$ & $123.70 \pm 1.12$ & $238.54 \pm 19.12^{*}$ & $12.03 \pm 1.19$ \\
\hline Canaga odorata & $2.38 \pm 0.29$ & $2.53 \pm 0.32$ & $2.36 \pm 0.83$ & $6.28 \pm 1.21$ & $2.15 \pm 0.25$ & $3.91 \pm 0.16$ \\
\hline Chrysanthemum indicum & $17.71 \pm 0.83$ & $23.61 \pm 5.43$ & $17.08 \pm 0.20$ & $21.14 \pm 0.57$ & $16.06 \pm 9.44$ & $18.98 \pm 0.59$ \\
\hline Cleistocalyx nervosum & $0.63 \pm 0.12$ & $3.92 \pm 0.05$ & $1.16 \pm 0.02$ & $4.85 \pm 0.05$ & $1.91 \pm 0.95$ & $12.67 \pm 0.28$ \\
\hline Clitoria ternatea & $2.42 \pm 0.54$ & $1.73 \pm 0.52$ & $1.65 \pm 0.18$ & $4.75 \pm 0.18$ & $4.34 \pm 0.60$ & $12.74 \pm 0.69$ \\
\hline Garcinia cowa & $0.39 \pm 0.00$ & $3.70 \pm 0.07$ & $67.18 \pm 0.03$ & $18.69 \pm 0.55$ & $20.90 \pm 0.81$ & $365.54 \pm 10.00^{*}$ \\
\hline Garcinia mangostana & $10.35 \pm 0.22$ & $18.92 \pm 1.45$ & $1.11 \pm 0.03$ & $155.73 \pm 0.29^{*}$ & $0.38 \pm 0.01$ & $112.79 \pm 14.87$ \\
\hline Hibiscus sabdariffa & $1.03 \pm 0.79$ & $2.94 \pm 0.20$ & $3.00 \pm 0.00$ & $9.23 \pm 0.25$ & $1.60 \pm 0.18$ & $4.06 \pm 0.65$ \\
\hline Jasminum officinale & $11.41 \pm 5.04$ & $2.73 \pm 1.16$ & $1.56 \pm 0.35$ & $6.23 \pm 0.43$ & $1.78 \pm 0.00$ & $12.56 \pm 0.38$ \\
\hline Mesua ferrea & $125.48 \pm 41.48$ & $47.57 \pm 1.52$ & $66.68 \pm 0.85$ & $46.77 \pm 0.33$ & $4.98 \pm 0.26$ & $24.59 \pm 0.62$ \\
\hline Metha cordifolia & $20.06 \pm 2.41$ & $0.81 \pm 0.13$ & $3.50 \pm 0.20$ & $9.97 \pm 0.17$ & $7.36 \pm 0.95$ & $7.73 \pm 0.93$ \\
\hline Mimusops elengi & $13.06 \pm 0.57$ & $17.14 \pm 4.48$ & $5.59 \pm 0.70$ & $18.55 \pm 0.42$ & $0.37 \pm 0.02$ & $2.30 \pm 0.16$ \\
\hline Nelumbo nuclfera & $11.81 \pm 0.27$ & $77.32 \pm 6.61$ & $55.98 \pm 9.43$ & $98.05 \pm 0.82$ & $7.63 \pm 2.46$ & $43.78 \pm 2.27$ \\
\hline Zingiber officinale & $5.35 \pm 0.54$ & $27.22 \pm 6.49$ & $4.43 \pm 0.02$ & $21.63 \pm 1.26$ & $20.35 \pm 0.44$ & $66.29 \pm 1.60$ \\
\hline
\end{tabular}

All values are presented as mean \pm SD of triplicate independent experiments. ${ }^{*} P<0.05$ compared with each plant extraction.

Table 7: Antibacterial activity of the combination of tea leaf and plant extract.

\begin{tabular}{ccccccc}
\hline \multirow{2}{*}{ Bacteria } & \multicolumn{2}{c}{ Aqueous extract of green tea combined with G. cowa } & \multicolumn{3}{c}{ Ethanolic extract of green tea combined with G. cowa } \\
\cline { 2 - 6 } & IZD $(\mathrm{mm})$ & $\mathrm{MIC}(\mathrm{mg} / \mathrm{mL})$ & $\mathrm{MBC}(\mathrm{mg} / \mathrm{mL})$ & IZD $(\mathrm{mm})$ & $\mathrm{MIC}(\mathrm{mg} / \mathrm{mL})$ & $\mathrm{MBC}(\mathrm{mg} / \mathrm{mL})$ \\
\hline E. coli & $14.00 \pm 1.73$ & 15.63 & 15.63 & $14.33 \pm 1.14$ & 15.63 \\
S. typhi & 0 & 31.25 & 31.25 & $18.00 \pm 2.00$ & 7.81 & 7.81 \\
S. dysenteriae & $13.33 \pm 0.58$ & 0.48 & 0.48 & $14.00 \pm 1.00$ & 3.90 & 15.90 \\
V. cholerae & $15.33 \pm 1.15$ & 31.25 & 31.25 & $16.67 \pm 1.15$ & 15.63 \\
S. aureus & $20.33 \pm 0.58$ & 0.97 & 0.97 & $20.67 \pm 0.58$ & 0.97 & 0.97 \\
\hline
\end{tabular}

All values are presented as mean \pm SD of triplicate independent experiments. IZD: inhibition zone diameter, MIC: minimal inhibitory concentration, MBC: minimal bactericidal concentration.

The aqueous extract of green tea combined with G. cowa presented inhibitory effect to inhibit E. coli, S. dysenteriae, V. cholera and S. aureus, with the diameter of the inhibition zones ranging from $14.00 \pm 1.73$ to $20.33 \pm 0.58 \mathrm{~mm}$. Moreover, combination of aqueous extract of green tea and G. cowa showed the lowest MIC and MBC against $S$. dysenteriae with the values of $0.48 \mathrm{mg} / \mathrm{mL}$, and presented the values of MIC and $\mathrm{MBC}$ ranging from 0.48 to $31.25 \mathrm{mg} / \mathrm{mL}$ against all enteric pathogenic bacteria (Table 7).

\section{Inhibitory effect of the combination of tea leaf with} plant extract on enteric pathogenic bacterial adhesion on Vero cells

The ethanolic extract of green tea combined with G. cowa was investigated on adhesion of enteric pathogenic bacteria including E. coli, S. typhi,
$S$. dysenteriae and V. cholera. Nontoxic doses of the extracts were selected to test on the Vero cells. After the incubation of the ethanolic extract of green tea combined with $G$. cowa and enteric pathogenic bacteria on a Vero cell, the combination extracts showed the highest inhibition of the adhesion of $V$. cholerae on Vero cells by $22.93 \pm 0.60 \%$. In addition, the combination of extracts inhibited the adhesion of all enteric pathogenic bacteria on Vero cells with the value ranging from $15.89 \pm 0.52 \%$ to $22.93 \pm 0.60 \%$. Moreover, the ethanolic extracts of green tea and plant extracts $G$. cowa could inhibit the adhesion of all enteric pathogenic bacteria on Vero cells with the value ranging from $13.42 \pm 0.14 \%$ to $23.39 \pm 0.18 \%$. The number of bacterial controls attached to the membrane of the Vero cells appeared higher than the bacteria treated with extracts (Table 8 and Figure 3). 

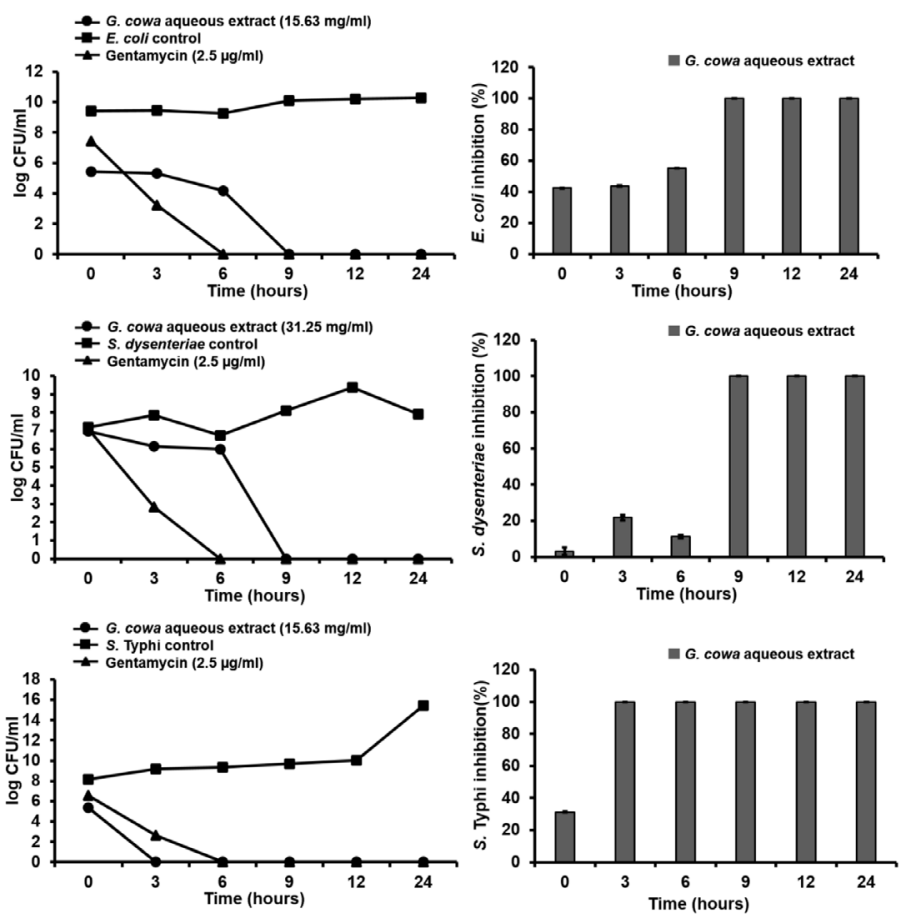

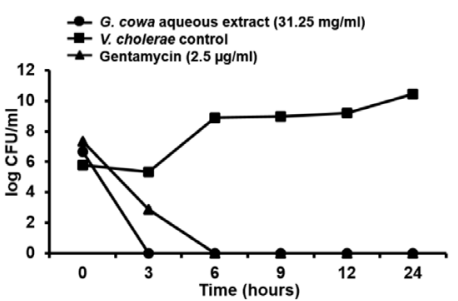

(A)

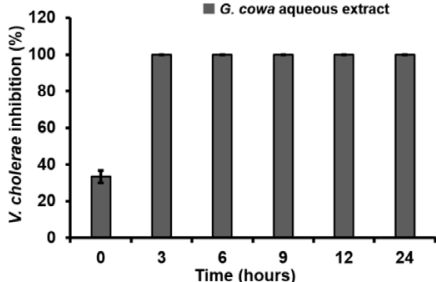

(B)
Figure 1: Time-kill kinetics of $G$. cowa aqueous extract against $E$. coli, S. dysenteriae, S. typhi and V. cholerae. Time-kill kinetics curve (A) and the percentage of inhibition at different times of killing (B).
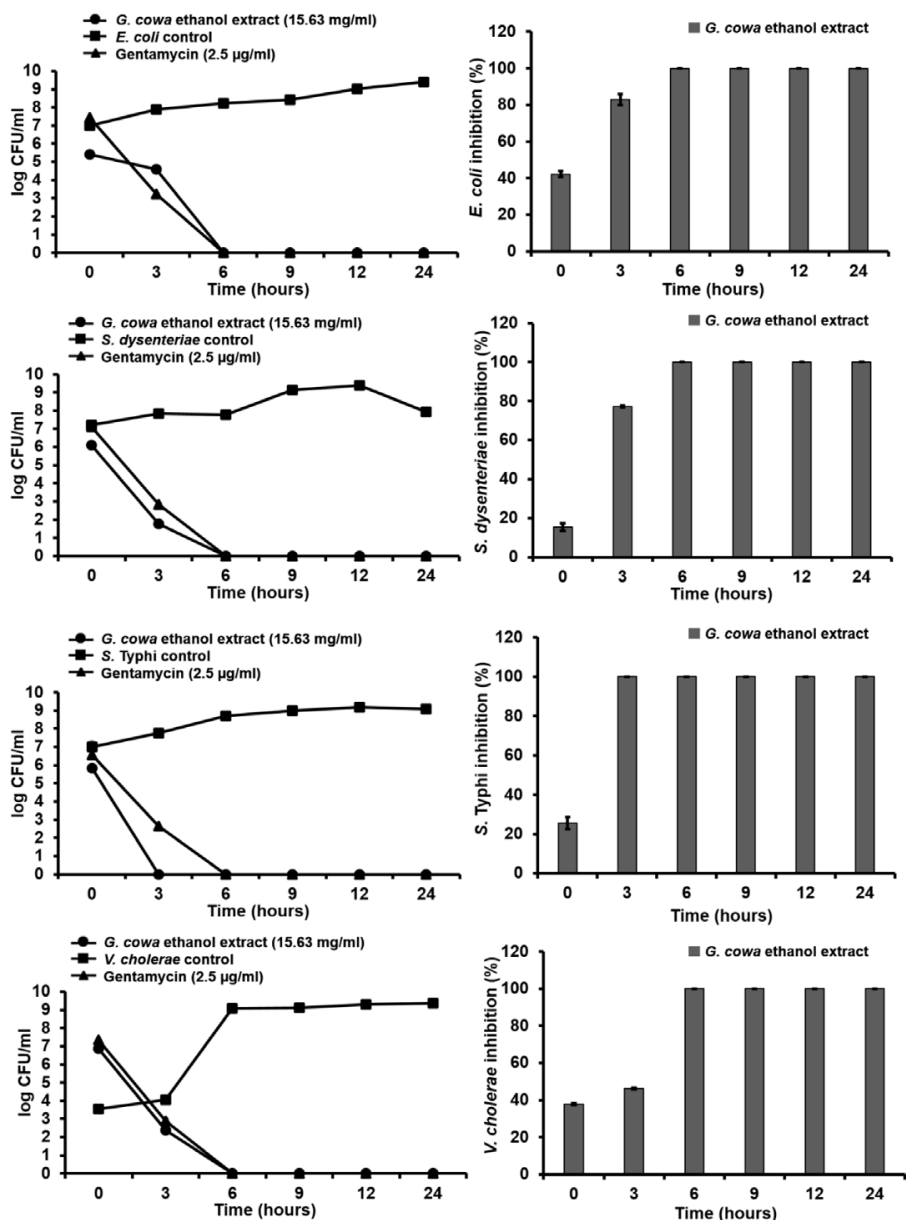

(A)

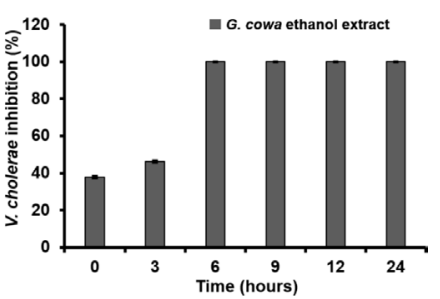

(B)

Figure 2: Time-kill kinetics of G. cowa ethanol extract against E. coli, S. dysenteriae, S. typhi and V. cholerae. Time-kill kinetics curve (A) and the percentage of inhibition at different times of killing (B).

Table 8: Inhibition of enteric pathogenic bacteria adhesion to Vero cells by the combination of tea leaf with plant extract.

\begin{tabular}{ccccc}
\hline \multirow{2}{*}{ Samples } & \multicolumn{4}{c}{ Adhesion inhibition (\%) } \\
\cline { 2 - 5 } & E. coli & S. typhi & S. dysenteriae & V. cholerae \\
\hline Green tea combined with G. cowa & $20.78 \pm 0.16$ & $15.89 \pm 0.52$ & $17.53 \pm 0.37$ & $22.93 \pm 0.60$ \\
Green tea extract & $21.42 \pm 0.46$ & $19.00 \pm 0.46$ & $21.10 \pm 0.11$ & $13.84 \pm 0.40$ \\
G. cowa extract & $17.35 \pm 0.39$ & $23.39 \pm 0.18$ & $21.91 \pm 0.23$ & $13.42 \pm 0.14$ \\
\hline
\end{tabular}

All values are presented as mean $\pm \mathrm{SD}$ of triplicate independent experiments.

\section{DISCUSSION}

Herbal medicine is the use of medicinal plants that includes one type of dietary supplement. Moreover, using herbal medicine as alternative medicine is rapidly growing in health systems and promotes beneficial health effects, along with Chinese medicine, Indian Ayurveda, Arabic medicine and traditional Thai medicine. ${ }^{[25,26]}$ Many of these practices use herbs that contain active ingredients, parts of plants, or combinations of plant materials. Herbal teas were also prepared as natural products such as green tea, black tea, peppermint, sage and thyme, which have been reported to have many biological activities, such as antiviral, antifungal and antibacterial activity. ${ }^{[27]}$ In this study, we examined the antibacterial activities of herbal tea as prepared by the combination of tea leaves with the medicinal plant. In addition, the phytochemical compounds and antioxidant activities of herbal tea were also studied. Tea leaves (green tea, oolong tea and black tea) and 14 medicinal plants were extracted using water and ethanol. These solvents are safe for humans when compared to organic solvents such as methanol or acetone. Moreover, the extraction by using ethanol solvent, widely used to remain phytochemicals in crude extracts and also used in the herbal medicine industry for therapeutic applications. ${ }^{[28]}$ According to these experiments, the ethanolic extracts of green, oolong and black tea could inhibit all enteric pathogenic bacteria; E. coli, S. typhi, S. dysenteriae, S. aureus and V. cholera. Similar results have been demonstrated by other studies. Green tea extracts could inhibit Gram-positive bacteria; Micrococcus luteus, S. aureus and Bacillus cereus. ${ }^{[29]}$ Earlier studies have reported that black tea could inhibit the 


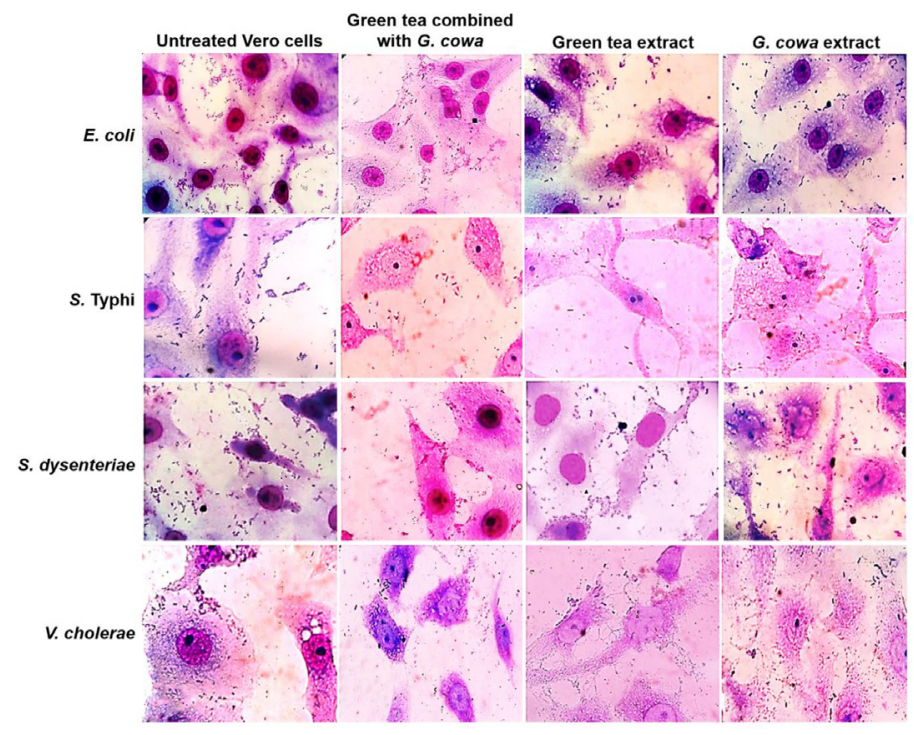

Figure 3: Giemsa staining of enteric pathogenic bacteria on Vero cells after being treated with the ethanolic extract of green tea combined with $\mathrm{G}$. cowa, green tea extract and G. cowa extract, respectively, and comparing with the untreated control. Adhesion of bacteria on Vero cells observed under oil immersion microscope (100X) after staining with Giemsa stain.

growth of S. aureus. ${ }^{[30,31]}$ However, this study demonstrated the inhibitory effects of green, oolong and black tea extracts on the growth of Grampositive and Gram-negative bacteria. Additionally, the extracts of green tea were revealed to be effective in inhibiting bacterial growth, more than oolong tea and black tea. We hypothesized that the differences in the antibacterial activities of the various teas correlated to the phytochemical compounds of each type of tea leaf. The determination of antioxidation, total phenolics and flavonoid content in tea leaf extracts showed the highest amounts in green tea, which also correlated with the antibacterial activity. Several studies have reported that catechins from green and black teas, particularly epigallocatechin gallate (EGCG) and epigallocatechin (EGC), inhibit the growth of many bacteria pathogens. ${ }^{[32]}$ In general, high polyphenol content such as phenolic and gallic acid were found in unfermented tea or green tea, whereas polyphenols were polymerized by tea processing in partial and complete fermentation of oolong tea and black tea, respectively. ${ }^{[7]}$ Moreover, catechins were identified as a major component in tea. Catechins make up about $25 \%$ of the dry weight of fresh tea leaves. ${ }^{[33]}$ Catechins, including epigallocatechin gallate (EGCG), epicatechins (EC), epigallocatechin (EGC) and catechins, were found in green tea, oolong tea and black tea. ${ }^{[34]}$

For medicinal plants, the aqueous extract of A. clypearia, C. nervosum, G. cowa and Mimusops elengi could inhibit all tested enteric pathogenic bacteria. In addition, the ethanolic extracts of A. clypearia, C. nervosum, G. cowa, M. elengi and N. nuclfera have the ability to inhibit all tested enteric pathogenic bacteria. G. cowa extracts were found to be effective against enteric pathogenic bacteria. Hence, the time-kill kinetics profile of G. cowa extracts showed bactericidal activity, which revealed the inhibition of enteric pathogenic bacteria within 9 h. G. cowa, commonly known as "Cha Muang" in Thailand, is a Thai local edible plant used for treating diabetes patients. ${ }^{[35]}$ Moreover, the leaves of G. cowa extracted from hexane and chloroform have the ability to inhibit Gram-negative bacteria and Gram-positive bacteria and such as E. coli, Bacillus coagulans, B. cereus and B. subtilis. ${ }^{[36]}$ In addition to antibacterial activity, G. cowa extracts were also reported to inhibit the fungal growth of Aspergillus flavus ATCC 46283. This strain produces aflatoxin B1 and other contaminants in foods. ${ }^{[37]}$ Therefore, phytochemical investigations of $G$. cowa extracts, especially ethanol fractionation, showed the highest content of flavonoids. G. cowa extracts also demonstrated antioxidation and phenolic compounds. Similar results have been expressed by Panthong et al. since G. cowa is rich in secondary metabolites, especially triterpenes, flavonoids, xanthones and phloroglucinols. ${ }^{[38]}$ The antibacterial, antioxidation and phytochemical compounds from this study suggested that herbal teas could be considered as prophylactic or primary formula treatment agents for enteric pathogenic bacteria infections and could promote health benefits.

The combinations of the extracts of green tea with G. cowa were selected to treat enteric pathogenic bacteria infections, because these plants presented the greatest activity to inhibit enteric pathogenic bacteria. Once combined, the ethanolic extracts of green tea and G. cowa revealed effective inhibition on enteric pathogenic bacteria. Previous studies show that the combination of extracts may enhance the activity of each extract. Green tea powder supplemented with mulberry leaf powder could greatly decrease pathogenic bacteria in the chicken gut. ${ }^{[39]}$ Previous studies have focused on the effects of herbal tea-drug interactions for therapy against pollen allergy in a rat model. After the rat's continuous ingestion of tenryocha or rooibos tea combined with the midazolam (MDZ) drug for two weeks, these teas can improve the effectiveness of MDZ on allergies by more than $50 \% \cdot{ }^{[40]}$ Epigallocatechin gallate (EGCG) was fractionated from green tea leaves and ampicillin-sulbactam, showed synergistic activity and was active against methicillin-resistance S. aureus (MRSA). ${ }^{[41]}$ The combination of catechin with ciprofloxacin inhibited $E$. coli that caused a chronic bacterial prostatitis in a rat model. ${ }^{[42]}$ Although the advantage of the combination of tea and medicinal plant extracts with drugs is to increase the antibacterial activity, the bacteria resistance from antibiotics may be found in long-term usage. Therefore, these combinations of tea with medicinal plants could contribute to the alternative treatment of bacterial infections.

Interestingly, the combination of green tea and G. cowa ethanolic extracts affected the adhesion of enteric pathogenic bacteria that was related to bacterial colonization. In this study, the effects of the combination of green tea and G. cowa could inhibit the adhesion of enteric pathogenic bacteria to Vero epithelial cells. After incubation of the ethanolic extract of green tea combined with G. cowa and enteric pathogenic bacteria on the Vero cell, the combination of extracts could inhibit the adhesion of all enteric pathogenic bacteria on the cells. However, the percentage of adhesion inhibition did not increase after treatment for $2 \mathrm{hr}$. Another study revealed that green tea could reduce the colonization of Helicobacter pylori in terms of gastric colonization in Mongolian gerbils. ${ }^{[43]}$ Green tea catechins especially EGCG, can cause cell membrane disruption and prevent DNA supercoiling, eventually leading to bacterial destruction. ${ }^{[7]}$ Moreover, this study demonstrated the first report for anti-adhesion of enteric pathogenic bacteria on the cells from G. cowa extracts. Another genus of Guava, namely G. cambogia could prevent the staphylococcal biofilm development. ${ }^{[44]}$ Hence, both green tea and G. cowa contained polyphenolic substances, which have been reported to bind with bacterial adhesion molecules and disturb the ability of receptor binding sites of the bacterial surface. ${ }^{[45,46]}$

\section{CONCLUSION}

These findings reveal that tea leaves; green, oolong and black tea, and fourteen medicinal plants in Thailand are potential sources of phytochemical compounds which have the ability to inhibit enteric pathogenic bacteria. The extracts of green tea and G. cowa displayed the greatest efficacy on bacterial inhibition with a high content of several phytochemical compounds, such as phenolics and flavonoid compounds, which correlate with the antioxidant activity. Moreover, this 
finding demonstrates the antibacterial activities of herbal tea with the combination of green tea with $G$. cowa extract. The efficacy of green tea and $G$. cowa extract combinations showed the effectiveness against enteric pathogenic bacteria, and could therefore inhibit enteric pathogenic bacteria directly. The findings reveal a new discovery of inhibitory effects against the adhesion of bacteria. This study emphasized the beneficial activity of tea leaves and medicinal plants in Thailand as potential agents for the treatment of enteric pathogenic bacterial infections. Herbal teas could be considered as the first alternative therapeutic agents for enteric pathogenic bacteria infections and could also promote health benefits.

\section{ACKNOWLEDGEMENT}

This research work was acknowledged Department of Biology, Faculty of Science, Chiang Mai University, and Chiang Mai, Thailand. We also would like to express our thanks to Julia Akins for language editing.

\section{Financial Support and Sponsorship}

This research study was supported by the Office of Research Administration, Chiang Mai University (CMU) and Thailand Research Fund-Research and Researchers for Industry (RRi) Master Scholarship, the Thailand Research Fund, grant no. MSD58I0104.

\section{CONFLICT OF INTEREST}

The authors declare that they have no conflicts of interest.

\section{ABBREVIATIONS}

$\mathrm{CD}_{50}: 50 \%$ cytotoxicity dose; CFU: Colony forming unit; DMSO: Dimethyl sulfoxide; DPPH: 2,2-Diphenyl-1-picrylhydrazyl; EC: Epicatechins; ECG: Epicatechin gallate; EGCG: Epigallocatechin gallate; FBS: Fetal bovine serum; GAE: Gallic acid equivalent; IC $_{50}$ : Half-maximal inhibitory concentration; IZD: Inhibition zone diameter; MBC: Minimal bactericidal concentration; MDZ: Midazolam; MEM: Minimum essential medium; MHA: Mueller Hinton agar; MHB: Mueller Hinton broth; MIC: Minimal inhibitory concentration; MRSA: Methicillin-resistance Staphylococcus aureus; QUE: Quercetin equivalent; SD: Standard deviation; WHO: World Health Organization.

\section{REFERENCES}

1. Clements A, Young JC, Constantinou N, Frankel G. Infection strategies of enteric pathogenic Escherichia coli. Gut Microbes. 2012;3(2):71-87. doi: 10.4161/ gmic.19182, PMID 22555463.

2. Donnenberg MS. Pathogenic strategies of enteric bacteria. Nature. 2000;406(6797):768-74. doi: 10.1038/35021212, PMID 10963606.

3. Klose KE. Regulation of virulence in Vibrio cholerae. Int J Med Microbiol. 2001;291(2):81-8. doi: 10.1078/1438-4221-00104, PMID 11437342.

4. Bertram GK. Basic and clinical pharmacology. 1st ed. New York: McGraw-Hill Medical; 2007;831-7

5. Okeke IN, Laxminarayan R, Bhutta ZA, Duse AG, Jenkins P, O'Brien TF, et al. Antimicrobial resistance in developing countries. Part I: Recent trends and current status. Lancet Infect Dis. 2005;5(8):481-93. doi: 10.1016/S14733099(05)70189-4, PMID 16048717.

6. Komes D, Horžic D, Belšcak A, Ganic KK, Vulic I. Green tea preparation and its influence on the content of bioactive compounds. Food Res Int. 2010;43(1):167-76. doi: 10.1016/j.foodres.2009.09.022

7. Namita P, Mukesh R, Vijay K. Camellia sinensis (green tea). Glob J Pharmacol. 2012;6:52-9

8. Cooper R, Morré DJ, Morré DM. Medicinal benefits of green tea: Part I. Review of noncancer health benefits. J Altern Complement Med. 2005;11(3):521-8. doi: 10.1089/acm.2005.11.521, PMID 15992239.

9. Sajilata MG, Bajaj PR, Singhal RS. Tea polyphenols as nutraceuticals. Compr Rev Food Sci Food Saf. 2008;7(3):229-54. doi: 10.1111/j.1541-4337.2008.00043.x, PMID 33467802

10. Nyfors S, Syrjänen R, Könönen E. Impact of antimicrobial exposure and betalactamase-producing bacteria on salivary beta-lactamase activity in infancy. Int J Antimicrob Agents. 2004;24(5):463-7. doi: 10.1016/j.ijantimicag.2004.06.014 PMID 15519478.
11. Handa SS, Khanuja SPS, Longo G, Rakesh DD. Extraction technologies for medicinal and aromatic plants. 1st ed. Italy: International Centre for Science and High Technology; 2008.

12. Venugopal R, Liu RH. Phytochemicals in diets for breast cancer prevention: The importance of resveratrol and ursolic acid. Food Sci Hum Wellness. 2012;1(1):1-13. doi: 10.1016/j.fshw.2012.12.001

13. Patel SH. Camellia sinensis Historical perspectives and future prospects. J Agromedicine. 2005;10(2):57-64. doi: 10.1300/J096v10n02_08, PMID 16236672.

14. Srivastava JK, Shankar E, Gupta S. Chamomile: A herbal medicine of the past with bright future. Mol Med Rep. 2010;3(6):895-901. doi: 10.3892/mmr.2010.377, PMID 21132119.

15. Malm C, Svensson M, Ekblom B, Sjödin B. Effects of ubiquinone-10 supplementation and high intensity training on physical performance in humans Acta Physiol Scand. 1997;161(3):379-84. doi: 10.1046/j.1365-201X.1997.00198.x, PMID 9401591.

16. Rafat A, Philip K, Muniandy S. Antioxidant potential and phenolic content of ethanolic extract of selected Malaysian plants. Res J Biotechnol. 2010;5:16-9.

17. Clinical and Laboratory Stands Institute (CLSI). Performance standards for antimicrobial disk susceptibility tests; CLSI Document M2. 9th ed. Vol. A9. MD: Clinical Laboratory Standards Institute; 2013a.

18. Clinical and Laboratory Stands Institute (CLSI). Methods for dilution antimicrobial disk susceptibility tests for bacteria that grow aerobically; CLSI Document M7. 7th ed. Vol. A7. MD: Clinical Laboratory Standards Institute; 2013b.

19. Owen RJ, Palombo EA. Anti-listerial activity of ethanolic extracts of medicinal plants, Eremophila alternifolia and Eremophila duttonii, in food homogenates and milk. Food Control. 2007;18(5):387-90. doi: 10.1016/j.foodcont.2005.11.004

20. Devi KP, Suganthy N, Kesika P, Pandian SK. Bioprotective properties of seaweeds: In vitro evaluation of antioxidant activity and antimicrobial activity against food borne bacteria in relation to polyphenolic content. BMC Complement Altern Med. 2008;8:38. doi: 10.1186/1472-6882-8-38, PMID 18613983.

21. Ghasemi K, Ghasemi Y, Ebrahimzadeh MA. Antioxidant activity, phenol and flavonoid contents of 13 citrus species peels and tissues. Pak J Pharm Sci. 2009;22(3):277-81. PMID 19553174

22. Reed LJ, Muench $\mathrm{H}$. A simple method of estimating fifty percent endpoints Am J Hyg. 1938;27:493-7.

23. Fleiszig SMJ, Zaidi TS, Preston MJ, Grout M, Evans DJ, Pier GB. Relationship between cytotoxicity and corneal epithelial cell invasion by clinical isolates of Pseudomonas aeruginosa. Infect Immun. 1996;64(6):2288-94. doi: 10.1128/ iai.64.6.2288-2294.1996, PMID 8675339.

24. Hartley CL, Robbins CM, Richmond MH. Quantitative assessment of bacterial adhesion to eukaryotic cells of human origin. J Appl Bacteriol. 1978;45(1):91-7. doi: 10.1111/j.1365-2672.1978.tb04202.x, PMID 359532.

25. World Health Organization (WHO). Traditional medicine strategy 2002-2005. Switzerland: World Health Organization; 2002

26. Pierce SC. Traditional Thai medicine: Buddhism, animism, Ayurveda. Arizona: Hohm Press; 2007.

27. Bansal S, Choudhary S, Sharma M, Kumar SS, Lohan S, Bhardwaj V, et al. Tea: A native source of antimicrobial agents. Food Res Int. 2013:53(2):568-84. doi: 10.1016/j.foodres.2013.01.032

28. Ganora L. Herbal constituents. 1st ed. Jefferson: Herbalchem Press; 2008

29. Chan EWC, Soh EY, Tie PP, Law YP. Antioxidant and antibacterial properties of green, black, and herbal teas of Camellia sinensis Pharmacogn Res. 2011;3(4):266-72. doi: 10.4103/0974-8490.89748, PMID 22224051.

30. Bancirova M. Comparison of the antioxidant capacity and the antimicrobia activity of black and green tea. Food Res Int. 2010;43(5):1379-82. doi: 10.1016/j. foodres.2010.04.020.

31. Chopra I, Greenwood D. Antibacterial agents: basis of action. Devon: Encyclopedia of Life Sciences; 2001.

32. Almajano MP, Carbó $\mathrm{R}$, Jiménez JAL, Gordon $\mathrm{MH}$. Antioxidant and antimicrobial activities of tea infusions. Food Chem. 2008;108(1):55-63. doi: 10.1016/j. foodchem.2007.10.040

33. Pereira VP, Knor FJ, Vellosa JCR, Beltrame FL. Determination of phenolic compounds and antioxidant activity of green, black and white teas of Camellia sinensis (L.) Kuntze, Theaceae. Rev Bras Plant Med. 2014;16(3):490-8. do: 10.1590/1983-084X/13_061.

34. Kaewkod T, Wangroongsarb P, Promputtha I, Tragoolpua Y. Inhibitory efficacy of Camellia sinensis leaf and medicinal plant extracts on Helicobacter pylor standard and isolate strains growth, urease enzyme production and epithelial cell adhesion. Chiang Mai J Sci. 2021;48:56-73.

35. Panthong K, Pongcharoen W, Phongpaichit S, Taylor WC. Tetraoxygenated xanthones from the fruits of Garcinia cowa. Phytochemistry. 2006;67(10):999-1004 doi: 10.1016/j.phytochem.2006.02.027, PMID 16678870

36. Negi PS, Jayaprakasha GK, Jena BS. Antibacterial activity of the extracts from the fruit rinds of Garcinia cowa and Garcinia pedunculata against food borne pathogens and spoilage bacteria. LWT Food Sci Technol. 2008:41(10):1857-61. doi: 10.1016/j.Iwt.2008.02.009. 
37. Joseph GS, Jayaprakasha GK, Selvi AT, Jena BS, Sakariah KK. Antiaflatoxigenic and antioxidant activities of Garcinia extracts. Int J Food Microbiol. 2005;101 (2):153-60. doi: 10.1016/j.ijfoodmicro.2004.11.001, PMID 15862877.

38. Panthong K, Hutadilok-Towatana N, Panthong A, Cowaxanthone F. Cowaxanthone F, A new tetraoxygenated xanthone, and other anti-inflammatory and antioxidant compounds from Garcinia cowa Can J Chem. 2009;87(11):1636-40. doi: 10.1139/N09-123.

39. Chen Y, Ni J, Li H. Effect of green tea and mulberry leaf powders on the gut microbiota of chicken. BMC Vet Res. 2019;15(1):77. doi: 10.1186/s12917-0191822-z, PMID 30841884

40. Matsuda K, Nishimura Y, Kurata N, Iwase M, Yasuhara H. Effects of continuous ingestion of herbal teas on intestinal CYP3A in the rat. J Pharmacol Sci. 2007;103(2):214-21. doi: 10.1254/jphs.fp0061311, PMID 17287587.

41. Hu ZQ, Zhao WH, Hara Y, Shimamura T. Epigallocatechin gallate synergy with ampicillin/sulbactam against 28 clinical isolates of methicillin-resistant Staphylococcus aureus J Antimicrob Chemother. 2001;48(3):361-4. doi: 10.1093/jac/48.3.361, PMID 11533000

42. Lee YS, Han CH, Kang SH, Lee SJ, Kim SW, Shin OR, et al. Synergistic effect between catechin and ciprofloxacin on chronic bacterial prostatitis rat model. Int J Urol. 2005;12(4):383-9. doi: 10.1111/j.1442-2042.2005.01052.x, PMID 15948727.

43. Lin YT, Kwon YI, Labbe RG, Shetty K. Inhibition of Helicobacter pylori and associated urease by oregano and cranberry phytochemical synergies. App Environ Microbiol. 2005;71(12):8558-64. doi: 10.1128/AEM.71.12.8558-8564.2005 PMID 16332847.

44. Chusri S, Sompetch K, Mukdee S, Jansrisewangwong S, Srichai T, Maneenoon K, et al. Inhibition of Staphylococcus epidermidis biofilm formation by traditional Thai herbal recipes used for wound treatment. Evid Based Complement Alternat Med. 2012;2012:159797. doi: 10.1155/2012/159797, PMID 22919409.

45. Díaz-de-Cerio ED, Verardo V, Gómez-Caravaca AM, Fernández-Gutiérrez $A$ Segura-Carretero A. Determination of polar compounds in guava leaves infusions and ultrasound aqueous extract by HPLC-ESI-MS. J Chem. 2015;2015:1-9. doi: 10.1155/2015/250919.

46. Ruggiero P, Rossi G, Tombola F, Pancotto L, Lauretti L, Del Giudice GD, Zoratti M. Red wine and green tea reduce $\mathrm{H}$ pylori- or VacA-induced gastritis in a mouse model. World J Gastroenterol. 2007;13(3):349-54. doi: 10.3748/wjg.v13.i3.349, PMID 17230601
GRAPHICAL ABSTRACT

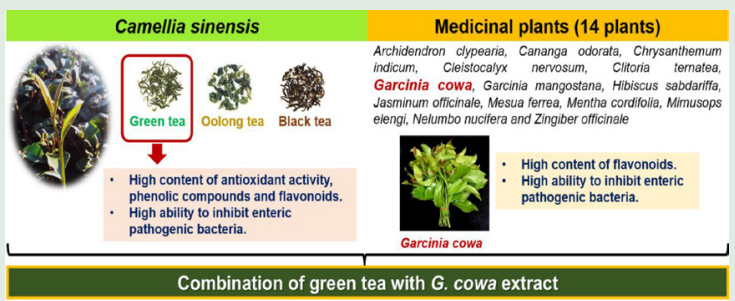

High ability to inhibit
Adhesion inhibition

\section{SUMMARY}

This research work demonstrated that herbal tea from the combination of green tea with $G$. cowa extract showed the effective inhibition against enteric pathogenic bacteria; E. coli, S. typhi, S. dysenteriae, S. aureus and $V$. cholerae. The findings revealed a new discovery of inhibitory effects against the adhesion of bacteria. Therefore, the extracts of green tea and G. cowa displayed the greatest efficacy on bacterial inhibition and antioxidant activity with high contents of several phytochemical compounds such as phenolic and flavonoid compounds.

Cite this article: Kaewkod T, Songkhakul W, Tragoolpua Y. Inhibitory Effects of Tea Leaf and Medicinal Plant Extracts on Enteric Pathogenic Bacteria Growth, Oxidation and Epithelial Cell Adhesion. Pharmacog Res. 2022;14(1):71-81. 